\title{
Civil Rights Tourism in Mississippi: Openings, Closures, Redemption and Remuneration
}

\author{
Ronald Loewe \\ Department of Anthropology, California State University at Long Beach, Long Beach, USA \\ Email: Ronald.Loewe@csulb.edu
}

Received August 30 $0^{\text {th }}$ 2013; revised October 22 ${ }^{\text {nd }}, 2013$; accepted November 21 $1^{\text {st }}, 2013$

\begin{abstract}
Copyright (C 2014 Ronald Loewe. This is an open access article distributed under the Creative Commons Attribution License, which permits unrestricted use, distribution, and reproduction in any medium, provided the original work is properly cited. In accordance of the Creative Commons Attribution License all Copyrights (c) 2014 are reserved for SCIRP and the owner of the intellectual property Ronald Loewe. All Copyright @ 2014 are guarded by law and by SCIRP as a guardian.
\end{abstract}

Unlike Georgia and Alabama which have had large civil rights museums for many years, Mississippi is just beginning to acknowledge and memorialize this part of its history. Since 2005, visitors to Neshoba County, infamous for the murder of civil rights workers Goodman, Schwerner and Chaney, have been able to obtain copies of the African-American Heritage Driving Tour which directs tourists to nine points of interest associated with the 1964 killings. In examining this development, my aim is to highlight the diverse political, economic and psychological motives underlying civil rights tourism and the formation of the Philadelphia Coalition which came together to commemorate the $40^{\text {th }}$ anniversary of the murders. In specific, this paper argues that civil rights tourism rests on four convergent trends: 1) the interest of the business community in re-imaging Mississippi, 2) the formation of a fragile alliance between white conservatives and moderate African-American leaders, 3) the search for redemption among white Christians, and 4) a growing concern over who will write Mississippi’s recent history.

Keywords: Tourism; Civil Rights; Politics of Memory; Race

Alabama was dangerous enough, but traveling through Mississippi would be even worse, Kennedy declared, facetiously reminding Shuttlesworth that even "the Lord hasn't ... been to Mississippi in a long time." Never one to miss a preaching opportunity, Shuttlesworth shot back: "But we think the Lord should go to Mississippi, and we want to get him there." (Raymond Arsenault, Freedom Riders: 1961 and the Struggle for Racial Justice, p. 206).

Touring the rest of Goat Hill, I kept encountering the same startling juxtaposition. A plaque beside the capitol identified the statehouse as both the home of the first Confederate Congress and the end point of the Selma-to-Montgomery civil rights march in 1965. Just a few paces away stood the Dexter Avenue Baptist Church, where Martin Luther King Jr. served as pastor in the 1950s and helped lead the Montgomery bus boycott. On the street outside stood two plaques. One noted that Dexter Avenue was the site of Jeff Davis's inaugural parade: "Dixie' was played as a band arrangement for the first time on this occasion." The other plaque told of the Dexter Church and the bus boycott... At times, this proximity of black and white icons became a bit strange (Tony Horowitz, Confederates in the Attic, p. 356).

\section{Introduction: From Civil War to Civil Rights}

Civil War tourism in the South is legendary. In addition to visiting the Vicksburg National Military Park with its 1325 historic monuments, its twenty miles of reconstructed trenches, and its 144 canons, one can now take a virtual, online tour of the grounds and stop at any of the 23 memorials that have been photographed and archived. One can also follow the site index to a detailed teacher's guide that contains numerous math projects as well as a variety of social studies assignments. For example, under the heading "Killing Commanders" students in grades four through twelve are asked to evaluate a general's performance based on the rate of fatalities in his unit.

In contrast, civil rights tourism is far younger and less developed; nevertheless, since 2005, visitors to the Community Development Partnership in Philadelphia, Mississippi have been able to pick up copies of the handsomely designed AfricanAmerican Heritage Driving Tour next to promotional literature for the Neshoba County Fair and the Choctaw Indian Fair. The twelve-page driving tour guide is not only packed with information about important African-Americans from the Philadelphia area, but contains a map and description of nine points of interest related to Freedom Summer and the murder of three civil rights workers, Michael Schwerner, James Chaney and Andrew Goodman, in 1964. For example, one can follow the map to the former Neshoba County jail where the civil rights workers were held briefly the night of the killings, the Bogue Chitto Swamp, where the burnt shell of Michael Schwerner's station wagon was discovered, and the Mount Zion Methodist Church, a center of civil rights activity which was torched by the $\mathrm{Ku}$ Klux Klan on June 16, 1964 ${ }^{1}$. The Church was rebuilt in 1966, and now hosts a memorial service to the slain civil rights workers each year in June. 
More recently, the Mississippi Development Authority's Tourism Division has opened the Mississippi Freedom Trail which links twenty-five sites associated with the civil rights movement. These include several important sites unveiled during a commemoration of the fiftieth anniversary of the freedom rides in 2011: 1) a marker by the Bryant store in Money, Mississippi where the young Emmett Till was killed in 1955, 2) the home of Medgar Evers, the NAACP field secretary killed in front of his home by a sniper in 1963, and 3) the Greyhound bus station in Jackson, where the freedom riders disembarked and were promptly arrested for trying to desegregate the terminal's all white bathrooms.

Although I had lived in Mississippi since August of 2000, it was not until the summer of 2005 when I agreed to cover the trial of Edgar Ray Killen, the Klansman accused and now convicted of masterminding the killings of the three civil rights workers, that I began to notice a concerted effort to publicize and memorialize the lives of its civil rights heroes. In fact, two years before, I was not even aware of the annual memorial held for the civil rights workers at the Mt. Zion Methodist Church. Quite by chance I came across a small notice in the Starkville Daily News announcing a memorial service to mark the $39^{\text {th }}$ anniversary of the killings, and decided to take my kids down for a history lesson.

Entering Philadelphia along Route 16 was pleasant and easy, but would certainly be surprising to visitors who expect the backwoods town depicted in Mississippi Burning. Signs of modernity abound. Indeed, the first thing that drivers see emerging from the verdant hills of Neshoba County is a large billboard announcing Geyser Falls, a new, 15-acre water park with 13 water slides. A few miles down the road is the monumental Gold Moon Casino, one of two casinos run by the Mississippi Band of Choctaw and home to 4700 Vegas-style slot machines (Loewe \& Hoffman, 2005). Like many American towns, the original town square has been hurt by the development of commercial strips lined with fast food restaurants and chain stores, but even here signs of newness could be found. Across from the newly remodeled courthouse-site of several historic trials-sits The Coffee Bean, a stylish internet café where one can order lattes and deli sandwiches. And just a few blocks from the eatery is the Philadelphia historic district where visitors can admire a collection of Neo-Georgian revival style homes and several historically significant buildings.

Despite the lack of publicity and audience, the 2003 event included a rousing call for justice by Leslie McLemore, a political science professor from Jackson State (and former member of the Jackson city council), and a moving speech by William Winter, a former Governor of Mississippi as well as the founder of the William Winter Institute for Racial Reconciliation $(\text { WWIRR })^{2}$. Several relatives of the slain civil rights workers were also in attendance. Still, the event was small enough that the media-a CBS affiliate from Columbus, MS, the Jackson

\footnotetext{
${ }^{1}$ In 1966 the Board of Stewards of the First Methodist Church of Philadelphia, a white church under the leadership of Clay Lee, voted unanimously to help the Mt. Zion congregation rebuild their church, and eventually enlisted the support of the entire Philadelphia Ministerial Association. However, when the Mt. Zion congregation refused to promise that the church would not be used for civil rights activities, the white community withdrew its support. As Florence Mars writes in Witness in Philadelphia: "The chairman of the Mt. Zion building committee, Cornelius Steele, told me he firmly refused the package deal to relinquish control of the church in exchange for white support... Cornelius told me he didn't know that would be the last meeting and thought he would see the men again” (1977: p. 180).
}

Free Press, The Clarion-Ledger, and a few local newspapers, soon ran out of VIPS and started talking with audience members, hoping to figure out why people had traveled so far for a memorial service.

By the following year, however, the Philadelphia Coalition, a consortium of business, civic and political organizations, including the local NAACP and the Chamber of Commerce, had been formed to commemorate the $40^{\text {th }}$ anniversary of the killings and to pressure the State's Attorney to retry some of the principals involved in the 1964 murders. Although seven individuals had been convicted of violating federal civil rights statutes in 1967 (Mars, 1977), prior to June, 2005, no one had ever been convicted for the murders of the three activists. An attempt to prosecute Edgar Ray Killen, the "kleagle," (the KKK "messenger" to the Grand Dragon), ended in an acquittal because a lone juror could not bring herself to convict a preacher.

In the end, however, the work of the Philadelphia Coalition and others paid off. The $40^{\text {th }}$ commemoration not only generated large audiences at two sites, the Philadelphia Coliseum and the Mt. Zion Methodist Church, but attracted a wide range of participants from the conservative Governor of Mississippi, Haley Barbour, to prominent liberals like David Kendall, now better known for defending Bill Clinton during his Senate impeachment trial, and many scholars, veterans of the civil rights movement, and relatives of Goodman, Schwerner and Chaney.

The recent emergence of civil rights tourism, of course, raises several interesting questions, not least of which is: why now? Has the political climate changed so dramatically that things that were unmentionable a generation ago are now acceptable topics of public discourse? Or has the symbolism inherent in a fortieth anniversary, a number of biblical importance, simply overcome the reluctance to acknowledge uncomfortable memories of the past? Here, it is worth noting that a similar coalition was formed on the twenty-fifth anniversary of the killings (1989), and a similar call for justice was issued by then Secretary of State Dick Molpus. In addition, at least one previous Attorney General, Michael Moore, contemplated prosecuting Edgar Ray Killen (personal communication, Rita Bender, November 15, 2006). In the end, though, Moore failed to follow through, and Secretary Molphus's “apology” for the killings in 1989, according to one source, only served to undermine his candidacy for Governor of Mississippi.

\footnotetext{
${ }^{2}$ The William Winter Institute, an affiliate of the University of Mississippi, was an outgrowth of President Clinton's 1997 call for a national dialogue on race relations, better known as One America: The President's Initiative on Race. Ole Miss, well-known for its violent resistance to desegregation in 1961, agreed to host a town meeting, and was later hailed by the President for hosting the most successful event of the initiative. That recognition, according to the WWIRR website, "encouraged the University to formalized its dialogue process with the creation of an institute to promote racial reconciliation and civic renewal.”

(http://www.olemiss.edu/winterinstitute.pages/aboutu.htm). Under the direction of Susan Glisson, the WWIRR was not only instrumental in bringing the Philadelphia Coalition together, but has developed a manual to help community organizers promote racial reconciliation in their communities, and is in the process of developing a speakers bureau, lesson plans for educators who want to teach about the civil right movement, and even a podcast of civil rights driving tours for each county in Mississippi. The WWIRR was also instrumental in passing Senate Bill 2718 which authorizes the Mississippi Department of Education to teach civil rights in Mississippi schools and creates the Mississippi Civil Rights Commission. "Our hope," writes Annette Hollowell (2006: 4), "is that with the advent of this bill Mississippi educators will leverage Civil Rights (sic) topics across subjects, for example, teaching Freedom Songs in music class, discussing SNCC leader and Algebra Project founder Bob Moses in math class, and incorporating local histories into social studies class.”
} 
More importantly, perhaps, who are the key agents or actors in this public drama? Does the emergence of civil rights tourism reflect a grassroots effort to affect change? Or is it better seen as a top down effort to change public perceptions of Mississippi and aid business investment more generally? In this case, we might ask whether the prosecution of Edgar Ray Killen and the emergence of civil rights tourism, are really one and the same? Here, it is worth noting the Philadelphia Coalition's call for justice and the unveiling of its new civil rights' tour guide occurred at the same event ${ }^{3}$. And what role have outsiders played? Is Jim Carrier, the author of a Traveler's Guide to the Civil Rights Movement, correct in his assertion that tourism has essentially been forced on southern communities? "It's not like they put out a sign one day and said, 'Come on down and see our civil rights history.' It's in response to people coming down here, lugging big history books, looking for these places." (In Dewan, New York Times, August 10, 2004). Or, is it simply, as the Director of the Winter Institute for Racial Reconciliation suggests, that all many desperately poor communities "have going for them is their civil rights history?” In other words, is it at bottom a question of economic survival?

Because of its diverse make-up, the Philadelphia Coalition provides not only a model for action, but a window onto the complexity and potential difficulties inherent in civil rights tourism and education. As I point out below, for example, it is clear that for some Coalition members (and non-coalition activists) the Killen trial, the $40^{\text {th }}$ anniversary of the killings, and the new tour, represented an "opening" which would finally reveal untold truths about local history, and, perhaps, lead to the prosecution of other Klansmen. Others, however, saw these events as "acts of redemption," and a way of putting "closure" on an event which has psychologically scared Philadelphia, MS for decades. Still, others viewed the formation of the Coalition as a way to "control the message" on an occasion when outsiders and the so-called liberal media would be shining its bright lights on Philadelphia.

While dissident memories (e.g., the views of civil rights veterans) are now moving more into mainstream, memories, as Steve Stern notes in The Memory Box of Pinochet's Chile (2006: p. 4), do "not unfold in a smooth linear fashion." nor are "memory struggles free of divisive internal dynamics within one or another memory camp." (Barahona de Brito et al., 2001; Gordillo, 2004; Stern, 2006; Zubrzycki, 2006). Indeed, not unlike South Africa, Guatemala, El Salvador, and nations of the southern cone, I believe Mississippi is now engaged in a contentious struggle over how much of its recent past shall be unburied, and who shall tell the story of these times. Here, it is important to point out that Philadelphia Coalition was ultimately not successful in unifying all civil rights activists or educators. Indeed, since 2005, there have been two competing memorials sponsored by members of the Mt. Zion Methodist Church rather than one, and many former freedom riders and SNCC activists, including Ben Chaney, the brother of James Chaney, consider the Philadelphia Coalition to be a sellout.

Mississippi, however, differs in one fundamental respect from Chile, Guatemala and other nations where the politics of memory is active and ongoing. While in the former, the parameters of the discourse, the key events, time frame, etc., are well established albeit remembered differently, in Mississippi, the question is which discourse, which civil conflict, and even, which century, will occupy the public consciousness. All this,

\footnotetext{
${ }^{3}$ See, for example, the videotaped press conference (Video from the Resolution Press Conference) on the Philadelphia Coalition website http://www.neshobajustice.com/.
}

as Horowitz points out in the opening epigram, can be seen in the uneasy juxtapositions that abound in Mississippi and other parts of the south, where street signs mark the intersection of Jefferson Davis Boulevard with Martin Luther King Drive.

\section{Methodology}

This project is based on standard ethnographic methods: participant observation, in-depth interviews with knowledgeable informants, and archival research. Participant observation began in 2003 when I attended the $39^{\text {th }}$ commemoration held to honor the slain civil rights workers, and began to talk with local civil rights activists and community leaders. I attended this commemoration for three consecutive years taking detailed field notes, and collecting commemorative programs and brochures. In June, 2005, I covered the trial of Edgar Ray Killen, and subsequently wrote a short article on the trial for the Cleveland Jewish News which is now posted on the Philadelphia Coalition website under Coalition News. I also attended part of the Chaney, Goodman and Schwerner Living Memorial Civil Rights Education Summit on June 22, 2005, a teachers conference sponsored by the William Winter Institute for Racial Reconciliation, the Philadelphia Coalition, UNESCO's Breaking the Silence Project, and the Neshoba Educational Foundation. Held the day after the Killen verdict was announced, the conference was intended to help elementary and junior high school teachers locate pertinent resources and develop effective strategies for teaching about the civil rights movement. In total, I interviewed more than twenty individuals including several employees of the Mississippi Office of Tourism, a number of civic leaders I met during the Killen trial, the three Neshoba County tour guides who lead civil rights tours, and several members of the Philadelphia Coalition.

The third part of the project involved reviewing written documents on tourism that I obtained through the research division of the Mississippi Office of Tourism, and articles on tourism, politics and civil rights in the Neshoba Democrat. Fortunately for me, the latter contains an electronic archive with coverage of the Goodman, Schwerner and Chaney killings which goes back forty years. For historical background I consulted Raymond Arsenault's extraordinary history of the civil right movement, Freedom Riders: 1961 and the Struggle for Racial Justice (2006), the files of the Sovereignty Commission (the official anti-civil rights agency of Mississippi from 1956-1973) which are available online through the Mississippi Department of Archives and History (MDAH), and the Civil Rights in Mississippi Digital Archive at the McCain Library of the University of Southern Mississippi. The latter, also available online, contains detailed oral histories of dozens of civil rights veterans ${ }^{4}$.

\section{Civil Rights Tourism as a Total Social Fact: Four Faces of a Phenomenon}

\section{A. Economics 101: Money Talks}

One of the first things that come to mind when people think of tourism is money, and there is no shortage of journalistic accounts of southern politicians discussing civil rights tourism as a new cornucopia for the region. Indeed, in his Pulitzer Prize

${ }^{4}$ The website of the Mississippi Department of Archives and History is located at: http://www.mdah.state.ms.us/arlib/contents/er/index.html The website of the Civil Rights in Mississippi Digital Archive is located at: http://www.lib.usm.edu/\%7Espcol/crda/index.html. 
winning travelogue of the South, Confederates in the Attic: Dispatches from the Unfinished Civil War, Tony Horowitz found several politicians and businessmen willing to speak bluntly about the bottom line. While Joe Smitherman, the chain smoking, eight-term mayor of Selma, was reluctant to talk to him around the civil rights era, except to correct the perception that Selma police attacked protesters with dogs, he spoke candidly of the city's decision to market the civil rights movement. "The idea was, what happened at the bridge, we've been stigmatized because of it for so long, why don't we sell it, too?” (1998: 365). Similarly, Will Tankersly, former chair of the Montgomery Chamber of Commerce, explained to Horowitz that civil rights tourism was not only a way to improve Alabama's reputation, but ultimately made good business sense. "The state is overflowing with resources," he said, "It's got a heck of a work ethic. I want to bring jobs here. But we've still got an image problem. When you're sitting in a boardroom in New York and hear about Fruit Loops waving rebel flags down here, it's bad for business" (1998, 359).

Echoing this sentiment in Mississippi, Jim Prince III, editor of the Neshoba Democrat and co-chair of the Philadelphia Coalition, notes the unique convergence between morality, drama and business in an interview published in The Nation following the trial of Edgar Ray Killen (Younge, July 11, 2005). "It's a captivating story... the dark of night, the Ku Klux Klan, you know, it's got all the elements for great drama, but it's a true story and a sad story... I tell people if they can't be behind the call for justice because it's the right thing to do, and that's first and foremost, then do it because it's good for business." (Ironically, Prince, an unabashed conservative, later noted that the remark about business was actually taken from an old Robert F. Kennedy quote and was an attempt to bridge the gap between liberals and conservatives (personal communication, January 10, 2007).

Although less sanguine about the matter, other members of the coalition, such as Eva Tisdale, a Mississippi native who participated in Freedom Summer, agrees that it was the prospect of financial gain that convinced many whites to support the call for justice. "We organized marches and we marched and there were no white people marching, not from Philadelphia. So I know the reason we came together is not the same reason for all of us” (Younge, July 11, 2005).

In fairness, however, it should be noted that there was no direct return on the five thousand dollars the Philadelphia Community Development Partnership invested in the Roots of Struggle Driving Tour by 2006. According to David Vowell, the Head of the CDP, the Partnership paid local residents $\$ 30.00$ to lead the tour, but didn't charge visitors who actually took the tour. In fact, it is difficult to track the economic impact of heritage tourism, let along civil rights tourism, in Mississippi since there are currently no reliable measures being kept. While the Office of Tourism's fiscal report for 2004 (published in February 2005) contains entries for gaming and for outdoor recreation, there are no entries for heritage or cultural tourism. The closest indicator of this kind of activity is a line item in one of the report's appendices that shows revenues from museum visits.

The main question at this time was whether the state legislature would finally support a civil rights museum, and whether Philadelphia, MS could capture the project as State Senator, Gloria Williamson, and many prominent Philadelphia officials hoped. In short, it was an investment, but ultimately one which failed to pay a dividend. While the state legislature did finally vote to fund a civil rights museum after many years of voting down similar proposals, Philadelphia lost out to Jackson, the state capitol, despite the CDP's many small efforts.

While there is little doubt in my mind that economic development and the creation of a favorable business climate are prime movers in the emergence of civil rights tourism, there is also a danger of overstating the importance of this motive, and repeating the rather simple equation between tourism and consumption which characterized anthropological writing on tourism in the 1970s (see Greenwood in Gmelch, 2004). Doing so, in my view, not only ignores the many tangible, if small scale, efforts at memorializing and honoring civil rights activists in Mississippi over the last forty years, but very sincere attempts to educate a new generation of students on civil rights history and, ultimately, improve race relations.

Although often reluctant to use the term "tourism," civil rights workers are clearly interested in preserving the memory of their work and getting others to see it. At a 2006 commemoration in Longdale, MS, for example, a veteran of the civil rights movement who maintains an archive in West Point, Mississippi was distributing handbills announcing that the building that housed the Council of Federated Organizations (COFO) in Jackson, a consortium of civil rights groups, and two adjacent buildings were being turned into a museum, archive and tourist attraction, and would be available for educational programs. As the brochure explains, COFO is "best known for organizing the 1964 Freedom Summer Project that brought over 1000 civil rights volunteers to Mississippi and spawned the development of the Mississippi Freedom Democratic Party."5

It should also be noted that at least one local resident, Nettie Cox, a retired African-American school teacher, has been leading unofficial civil rights tours in Neshoba country since the early 1970s. Each summer, until about 2004, Operation Understanding, a mixed group of Blacks and Jews, would send down as many as 70 high school students from Washington and Philadelphia to learn about Freedom Summer and the Neshoba County killings. Although Ms. Cox initially felt that working with the Philadelphia Coalition and the Chamber of Commerce would be "selling out," she eventually agreed to work on the brochure (discussed above), because she was concerned that the information that she and a cousin had collected would be lost. "Sometimes,” as Ms. Cox put it, “you catch more bees with honey than with vinegar... I just tucked my tail and worked on the brochure (personal communication, June, 2005).” Ms. Cox is now one of three African-Americans from the Philadelphia area who accompanies tour buses to points of interest associated with the 1964 killings.

Indeed, while the Office of Tourism provides the imprimatur of officialdom or statehood on civil rights tourism, it could be argued that it has done little more than link a series of monuments which were created by black churches, civil rights activists and family members. While Mississippi is unarguably behind other southern states in acknowledging and memorializing key figures of the civil rights movement, there are, nonetheless, numerous private monuments and a few small public museums. Among these are the engraved tombstones for Goodman, Schwerner and Chaney at both the Mt. Zion Methodist Church

\footnotetext{
${ }^{5}$ Up until 1964 the Mississippi Democratic Party excluded African-Americans from its delegation to the National Democratic Convention. In response to this racist policy, the Mississippi Freedom Democratic Party held its own primary and later challenged the credentials of the regular state delegation at the 1964 national convention.
} 
outside Philadelphia, and the Nebo Missionary Baptist Church, another participant in Freedom Summer, in Philadelphia proper. There is also a memorial in Lauderdale County, Mississippi dedicated to James Chaney. In addition, there is a collection of civil rights memorabilia at Tougaloo College, an historic black college in Jackson, MS, and a Civil Rights Movement Driving Tour available through the Jackson Convention Center which lists various civil rights sites, including the home of Medgar Evers.

And, as Jim Carrier remarks in the Traveler's Guide to the Civil Right Movement, there are many other places associated with the civil rights movement, a movement carried out by ordinary people, that are either unmarked, increasingly difficult to find or falling down (2004: 257-264) ${ }^{6}$.

\section{B. Politics 101: Coalition Building and Its Discontents}

While the civil rights trails that link communities throughout Mississippi, and the many sites along the way, are only possible because of dozens, if not hundreds, of small acts of preservation, storage and memorialization, large scale projects and the establishment of a civil rights museum, scheduled to open in 2017, is difficult to imagine without the kind of coalition building that occurred in 2004. In fact, the Philadelphia Coalition, an organization which brought together moderate African-American leaders like Leroy Clemons, President of the local NAACP, and James Young, Head of the Neshoba County Board of Supervisors, with white conservatives like Jim Prince III, the editor of the Neshoba Democrat, and, ultimately, Haley Barbour, the Republican Governor of Mississippi, can best be understood as an historic exchange, both material and symbolic, between a conservative political elite which had done little to promote civil rights during the previous 40 years, and a segment of the African-American community that lacked political clout.

"For years," as Sheila Byrd notes, "black state lawmakers have introduced bills to jump start planning for a civil rights museum only to have the legislation die under a cloud of discussion over cost and expense." (See "Civil Rights Museum for State Overdue, Some Say,” April 16, 2006). However things

\footnotetext{
$\overline{{ }^{6} \mathrm{McC} \text { comb, Mississippi provides a perfect example. In response to pressure }}$ from the Kennedy administration to end the freedom rides and pursue less provocative activities like voter registration, Bob Moses, in collaboration with C.C. Bryant and other local supporters, began a voter registration drive in the southwestern town of McComb in August 1961, making McComb the beachhead of a new civil rights strategy. Although initially successful in registering black voters in McComb and rural Pike County towns like Amite and Liberty, it soon became clear that voter registration was as "provocative" as the effort to desegregate interstate transportation in the Deep South. Moses was severely beaten by white vigilantes on August 29th while escorting two black men to the Amite courthouse to register to vote. (Arsenault, 2006: pp. 396-402). Then in late September, Herbert Lee, the co-founder of the Amite NAACP, an organization that had been forced to operate underground for several years, was murdered by E.H. Hurst, the State Representative from the area and an outspoken segregationist. Lee's apparent "crime" was the intransigence he demonstrated by agreeing to drive Moses around the county and help register blacks to vote (2006: 442-3). However, rather than temper the enthusiasm of local students, the beatings and violence spawned the formation of the Pike County Nonviolent Movement and attempts to desegregate the lunch counters at the McComb Greyhound station and the local Woolworths (2006: 400-402). Still, as Carrier notes, there is no visual trace of this historic campaign in the local landscape. "In towns with some of the most heroic events, McComb, Greenwood, Hattiesburg, a Confederate soldier on a pedestal still rules the public square. A stranger wandering Mississippi would have almost no idea that a revolution envied by the world took place there (2004: 258)."
}

began to change after Haley Barbour's attendance at an event commemorating the $40^{\text {th }}$ anniversary of the murders of Goodman, Schwerner and Chaney at the Philadelphia Coliseum on June 20, 2005. In the 2006 legislative session, lawmakers passed a resolution to create a study group made up of university professors to look into the feasibility of establishing a civil rights museum, and on December 19, 2006 the study group recommended that a museum be built in Jackson. (See "Jackson Proposed As Site For Mississippi Civil Rights Museum,” Associated Press, December 22, 2006). Finally, in April, 2011 the Mississippi State Legislature approved twenty million dollars to fund the construction of new museum after Governor Barbour testified in favor it.

In short, while African-American leaders in the coalition, including some veteran civil rights workers, gave legitimacy to their Republican coalition partners, the forces surrounding Haley Barbour were able to bring along more conservative legislators who, up until then, had blocked funds for the construction of a museum. However, the alliance did not come without a heavy cost. Left in its wake was a bitter split in the Philadelphia AfricanAmerican community leading to two separate commemorations, one at the historic Mt. Zion Methodist Church and a second at the Longdale Community Center, and the marginalization of some of the most dedicated civil right activists of the 1960s.

The events which led to this historic split occurred during the preparation for the 40th annual memorial for Goodman, Schwerner and Chaney. For many years the annual memorial service had been held at the Mt. Zion Methodist Church in Longdale, MS; however, the leadership of the Philadelphia Coalition thought the Mt. Zion location was too small to host an event that might draw as many as 3000 people, and opened negotiations with the Mt. Zion planning committee to move the event to the Philadelphia Coliseum, a large sports arena in downtown Philadelphia. Some church members, however, were not happy about moving the event. Shirley Nichols, a long-time member of Mt. Zion is quoted in the Neshoba Democrat as saying “... I have a problem with them wanting to take the commemoration downtown ... for so long nobody acted like they even knew we were out here (See "Shirley Nichols Finds a Seat in the Back Row,” June 24, 2004).

There was also, apparently, a lot of debate about who should be invited to speak. Ben Chaney, brother of the deceased James Chaney, was upset that the Philadelphia Coalition had invited Governor Haley Barbour since the conservative Governor not only sports a confederate flag on this lapel, but had not endorsed the call for justice (e.g., the call to prosecute former Klansmen). On the other hand, one member of the Philadelphia Coalition complained that a group formed around John Steele, the son of Mt. Zion's former minister and civil rights leader Cornelius Steele ${ }^{7}$, kept insisting that more and more speakers be added to an already lengthy list of dignitaries. Eventually, it was decided that the memorial service would proceed in two phases; the first phase, would be held at the Philadelphia Coliseum, and the second phase, including the traditional wreath laying ceremony, would be held at Mt. Zion. Tour buses would

\footnotetext{
${ }^{7}$ According to the story told at the 2006 memorial service, Cornelius Steele had tried to register to vote in 1955, but was told by the registrar that "they needed time to think about it," and that Steele should return the following year. Next year when Steele returned he was told that he could vote as long as he didn't tell any of his friends. This was a compromise he couldn't agree to so he declined to register. He tried once more in 1958 only to be told that he couldn't register unless he knew how many bubbles there were in a bar of soap.
} 
ferry observers between the two events, and a close circuit television was set up at the coliseum so others could view the proceedings without traveling to Mt. Zion Methodist Church.

The final compromise, however, did not prevent bitter recriminations on both sides. In an article published in the Neshoba Democrat on June 24, 2004 (see “Neshoba acknowledges' 64 murders"), Reverend Steele is described "as a convicted felon from California with Neshoba County ties," and Ben Chaney is chastised for boycotting the commemoration, and launching a "five minute tirade before television cameras" in which he "claimed that the [Philadelphia] coalition 'used Negroes to do their bidding' to pull off the event."

The dual commemorations, held simultaneously in 2005, and especially 2006, provide a fascinating study in contrasts. The memorial held at Mt. Zion in 2006 followed a standard religious format and was oriented toward the past, to the events of 1964. Following a welcome by Leroy Clemons, the co-chair of the Philadelphia Coalition and the head of the local NAACP, the Reverend Ed King led the invocation by reading from scripture and leading the congregants, dressed in formal attire, in prayer and song. After lighting candles for Chaney, Goodman and Schwerner, and a tribute by Fent DeWeese, another member of the Philadelphia Coalition, several guest speakers provided short comments, followed by an enthusiastic rendition of "We Shall Overcome." The ceremony concluded with the traditional laying of a wreath on a tombstone dedicated to the civil rights workers.

In contrast, the alternative memorial, organized by John Steele, was more like a political rally. The event was held over a three day period in a wooded field in front of the Longdale Community Center, a cinder block construction which was only partially rebuilt following a fire in 1982. According to Steele the fire was simply "payback for twenty years of organizing in Neshoba County” (personal communication, June 2006). In place of the neatly folded handbills given out at Mt. Zion, participants at the alternative celebration were given a weighty, fifty-two page packet which not only contained detailed biographies of the twenty-five civil rights veterans who were invited to speak, but a short tribute to Andy Goodman, and a four page timeline of Mississippi's Freedom Summer complete with citations from four different histories (Dittmer, 1994; Cagin and Dray 1989; Bruner 1994; Sellers and Terrell, 1990). The packet also contained a lengthy excerpt from Cagin and Dray's study, We Are Not Afraid: The Mississippi Murder of Goodman, Schwerner and Chaney, which highlights the involvement of Olin Burrage, the owner of a trucking company who allegedly arranged for the disposal of the victims' bodies on his property. Burrage is one of the few alleged accomplices who are still alive and living in Philadelphia, MS.

In addition to many poignant and sometimes disturbing stories by movement veterans, the three day affair included freedom singing at regular intervals by the SNCC singers, breakout discussion groups to develop strategies for pressuring the district attorney to pursue other unresolved civil right cases, a workshop on non-violence led by Diane Nash ${ }^{8}$, one of the icons of the civil rights movement, a showing of a new film entitled "Why Only Killen?”, and a session entitled “Telling It Like It Is" in which individuals were invited to discuss recent, suspicious

${ }^{8}$ Nash not only helped to found SNCC (the Student Non-Violent Coordinating Committee), but was the unofficial leader of the 1960 lunch counter sit-ins in Nashville. Nash also took charge of the Freedom Rides in 1961 after CORE had decided to cancel them following a series of violent attacks in Birmingham, AL (Arsenault, 2006: pp. 179-185). jail house deaths along the Gulf Coast. In short, unlike the Mt. Zion commemoration, the Longdale "commemoration" was firmsly rooted in the present and the future through its emphasis on ongoing racial violence and the steps that should be taken to combat it.

\section{Psychology 101. Stigma, Stain, Catharsis and Redemption}

"To understand Neshoba County, you have to live here a hundred years”, Common saying, opening epigram to Witness in Philadelphia, 1977.

While economics and politics are crucial to understanding the growth of civil rights tourism in Mississippi, it would be wrong to ignore the Christian underpinnings of civil rights tourism, and the need for redemption. Oral and written accounts by Coalition members and other residents continually emphasize the stigma and embarrassment of being from Neshoba County and the need to be cleansed of the community's sin.

An early example of this sentiment can be found in a statement issued on December 4, 1964, the day the FBI made its first arrests in connection with the murders of Goodman, Schwerner and Chaney, by the Ministerial Association of Philadelphia. Authored by Clay Lee, the new minister of the First Methodist Church of Philadelphia, the pronouncement was made as a "matter of Christian conscience" and noted the "element of shame to all, that there would be among us those accused of such a crime..." (Mars, 1977: p. 142).

The statement by the Ministerial Association, however, was far from the common sentiment of Neshoba County residents in 1964. As Florence Mars, a prominent member of the community, and the courageous author of Witness in Philadelphia, goes on to note, residents of Philadelphia were generally more interested in raising funds to defend the suspects, or blaming the Meridian branch of the Ku Klux Klan for the killings, than inseeking justice. Indeed, Mars, one of the few white residents to testify before a grand jury, was despised by the community for years, and continually threatened by the Ku Klux Klan. ${ }^{9}$ Nonetheless, ten years later, Mars quoting Stanley Dearman, then editor of the Neshoba Democrat, pointed out that a sense of "corporate guilt" $(1977,278)$ had begun to set in, and that this, more than anything, allowed school desegregation to go ahead smoothly ${ }^{10}$.

The release of Mississippi Burning also contributed to a sense of defilement or stain as Dawn Lee Chalmers, a white ${ }^{9}$ Describing her testimony in Witness in Philadelphia, Mars writes: “... the real purpose of my testimony would be to let the grand jury know there were white citizens in Neshoba County concerned about the Ku Klux Klan and the brutality of the sheriff's office... I was then asked about the reputation of the sheriff in regard to his treatment of Negroes. I said that after Lawrence Rainey took office in January, 1964, there had been constant stories of brutality and that his reputation was widely known, not only among Negroes I knew but in the white community as well. One man asked me, I thought rather adamantly, what I had against the Ku Klux Klan. The question caught me off guard and I said that for one thing they didn't like Catholics. In Biloxi, a Gulf Coast town with a substantial Catholic population, the answer was acceptable. It was fortunate that I didn't slip and say the Klan didn’t like Negroes (1977: p. 135).”

${ }^{10}$ There is a corporate guilt, something that very much involves the life of the town. They could have reacted differently, but there was no leader... The school integration has gone smoothly and this is a great achievement... People knew they didn't want anything resembling this [the murders of the three civil rights workers] to happen again. The futility of making such a stand is very clear, and the community is gradually changing” (1977: p. 278). 
member of the Philadelphia Coalition, reveals in an interview with Debbie Elliot from National Public Radio (June 17, 2004):

I knew about the murders of the three civil rights workers... but we never learned about this in school. I remember asking a teacher of mine about it because I knew about it, and she said, "Oh, we're not going to discuss that today." It was just really shoved under. And it was-I didn't understand that then. I understand now that it's such a stain. It's such a negative thing that nobody wanted to deal with it. When I saw Mississippi Burning I was at Ole Miss [University of Mississippi], and we were all-it was a whole group of us from all over Mississippi. I don't think anybody there was from out of Mississippi, but they didn't know anything about it. They were looking at me like "oh my gosh." This happened where you lived. And umm, I said yeah, but this is kind, you know-I was just trying to kind of back out it. I was just like oh I don't want-this is awful. I was embarrassed. I thought those three men came down here to do what was right.

Most recently, Rita Schwerner Bender, the widow of Micheal Schwerner, commented on both the number and sincerity of residents who approached her seeking "absolution" during the 2005 trial of Edgar Ray Killen:

One of the most fascinating experiences was the number of people who sat in the courtroom both black and white and sought me out to talk about their life experiences and seemed to be looking for absolution from me. It was very genuine. There was a 55-year-old state trooper... who had tears in his eyes, who told me and my husband... that when he joined the state patrol he knew there were some very bad people on it, but that you can't tell young people about it, and he had tears in his eyes (personal communication, November 15, 2006).

Consequently, it's not surprising that meetings of the Philadelphia Coalition are often described as "cathartic" or "soul cleansing" experiences. In an editorial in the Neshoba Democrat (June 2, 2004) a couple weeks before the $40^{\text {th }}$ anniversary, the editor and co-founder of the Philadelphia Coalition noted that: "The Philadelphia Coalition has spent the better part of the last two months immersed in... cathartic, soul-cleansing, experiences as members have come to understand each other, the hurts and the fears, the guilt and the shame, as their mission evolved into a single minded quest for justice and redemption."

This, however, should not be seen as evidence that the majority of Philadelphia residents are seeking redemption or support the establishment of a civil rights museum in Philadelphia. As a legislative aid I spoke with candidly noted, "if residents had to vote on it, [the museum] wouldn't come to Philadelphia” (personal communication, November 10, 2006).

\section{History 101: Who Shall Speak for Neshoba County?}

Last but not least, the emergence of the Philadelphia Coalition and its civil rights brochure can be seen as an attempt to "control the message," and prevent "outsiders" and "radicals" from making negative comments about Neshoba County. In a June 30, 2004 editorial in the Neshoba Democrat, Jim Prince III, editor and co-chair of the Philadelphia Coalition emphasized the importance of the Coalition as a medium for shaping coverage of the $40^{\text {th }}$ anniversary and of Neshoba County. "Some criticized, more privately than publicly, the work of The
Philadelphia Coalition... without realizing just what its sheer existence prevented. Behind the scenes a fierce battle was raging between the coalition and radicals who wanted to come in and take over the observance, to proclaim that nothing has changed in Philadelphia, MS., and use that lie as a fundraiser (In Grouper, Labor Paeans, September 2004)."11. Similarly, in an article titled "Economic Impact of Commemoration Noted," Leroy Clemons, President of the local NAACP, and the other co-chair of the Philadelphia Coalition, angrily intoned that the Coalition's work was about changing the image of Philadelphia and Neshoba County. "We've had a major impact on that so far because we are the ones that are speaking now. In the past, we've had these guys coming in from California, from New York. They want to come in and portray Neshoba County the way they saw it 40 years ago (June 24, 2004). The sad irony, of course, is that the "radicals" Prince and Clemons are referring to include the brother of James Chaney and the widow of Michael Schwerner, and the reference to "outside agitators" matches both in tone and substance the rhetoric that helped fuel animus toward civil right workers in 1964.

\section{Conclusion}

In conclusion, I can only reiterate that the emergence of civil rights tourism in Mississippi is the result of a fragile and somewhat unusual convergence of different interest groups ranging from liberal to conservative. It is, in part, an outcome of a progressive-minded business community which wants to attract visitors to Mississippi and to promote investment in the state. Although recently converts to the cause of civil rights, the influence of this group is notable. Two days after the Philadelphia Coalition and the Philadelphia Board of Supervisors announced their call for justice, Attorney General Jim Hood announced that he would seek federal assistance in the prosecution of Edgar Ray Killen. As noted above, this sector of the community has also worked through the Mississippi Office of Tourism in order to build a trail connecting the many small memorials and sites that civil rights workers have built and nurtured over the years.

The work of the Coalition, however, is also partly a response to outside pressure, to the additive effects of many outsiders, including foreign journalists, who have ventured to Mississippi to find out exactly where the gruesome events of 1964 transpired, and to the fact that civil rights murders have been successfully prosecuted in many other states over the last fifteen years. "Since 1989 when the Neshoba case was first re-examined," writes Jim Prince III in an editorial, "authorities in six states have reopened 22 civil rights murders that led to 21 convictions, two acquittals and one mistrial. So the pressure is on" (Neshoba Democrat, April 21, 2004).

For many others, however, tourism and education are ends in themselves, ways of remembering events and individuals who have been largely ignored by the government and by elementary school curricula. In addition to avowed Christians who speak about removing stains of the past and seeking redemption, this group includes veterans of the civil rights movement and activists who speak about the need for truth and justice. No veteran

\footnotetext{
${ }^{11}$ While Ira Grupper does not provide a complete citation for this quote, Jim Prince III verified the statement when we spoke, and added that he told some of Ben Chaney's supporters at a coalition meeting that "they were welcome in Philadelphia, that they would be fed, but once they crossed county lines, the coalition was in charge (personal communication, January 10, 2007).”
} 
of the civil rights movement I spoke with was opposed in principle to building a museum or having a tour. Activists are painfully aware of the ignorance that surrounds the events of 1964 and the larger history of the civil rights movement, but there is almost always a sense of ambivalence, a lingering question about who will be placed in charge of the memorials and the tours, and what will ultimately be said.

The Freedom Rides, as Arsenault points out in the conclusion to his monumental history, may serve as a case in point. Although the Kennedy administration and the Interstate Commerce Commission had made no attempt to enforce existing legislation (Morgan vs. the Commonwealth of Virginia) favoring desegregation of bus lines and terminals in the South prior to the Freedom Rides, and were reluctant to provide federal protection to the freedom riders throughout 1961, the administration was successful in attributing the gains brought about by non-violent direct action to "governmentally administered gradualism (2006: 504).” A December, 1961 press release recounting the Administration's achievements in the area of civil rights lauded the ICC's belated order to desegregate interstate travel facilities, and "the government's role in bringing about 'substantive progress' in transit desegregation, but barely mentioned the Freedom Riders (2006: 504).

In short, the question is not whether something should or will be said, but whether it is an opening or a closing, a beginning or an end. As Rita Schwerner Bender comments in a letter to Haley Barbour on July 7, 2005:

Recently, after the verdict and sentencing in the Edgar Ray Killen trial in Neshoba County, you indicated your belief that this closed the books on the crimes of the civil rights years, and that we all should now have "closure"... People in positions of public trust, such as you, must take the lead in opening the window upon the many years of criminal conduct in which the state, and its officials, engaged... So please do not assume that the book is closed. There is yet much work to be done. Please don't squander the moment by proclaiming that the past does not inform the present and the future (In Howard Ball, September 25, 2006).

In short, as Faulker's Gavin Stevens, native son of the fictional Yoknapatawpha County, MS, reveals in Requiem for a Nun (1959: 33), “The past is never dead. It's not even past." A new chapter has begun. What is written remains to be seen.

\section{REFERENCES}

African-American Heritage Guide (2005). Mississippi development authority division of tourism.

Arsenault, R. (2006). Freedom riders: 1961 and the struggle for racial justice (Pivotal Moments in American History). Oxford: Oxford University Press.

Ball, H. (2006). It's time Mississippi established a truth and reconciliation commission. Electronic Document. http://hnn.us/articles/29718.html

Barahone De Brito, A., Gonzalez Enriquez, C., \& Aguilar, P. (2001) The politics of memory: Transitional justice in democratizing societies. Oxford Studies in Democratization, Oxford: Oxford University Press.

Bruner, E. R. (1994). And gently he shall lead them: Robert Parris Moses and civil rights in Mississippi. New York: New York University Press.

Byrd, S. (2006). Civil rights museum for state overdue, some say. Associated Press, Electronic Document.
http://clarionledger.com/apps/pbcs.dll/article?AID=/20060416/NEW S/604160382/1

Cagin, S., \& Dray, P. (1989). We are not afraid: The Mississippi murder of Goodman, Schwerner and Chaney. New York: Bantom Books.

Carrier, J. (2004). Traveler's guide to the civil rights movement. New York: Harcourt.

Dewan, S. (2004). Civil rights battlegrounds enter world of tourism. New York Times on the web, August 10, Electronic document. http://query.nytimes.com/gst/fullpagetml?res=9904E0DC1E3CF933 A2575BC0A9629C8B63\&sec=travel\&spon $=\& p$

Dittmer, J. (1994). Local people. Urbana, IL: University of Illinois Press.

Economic Impact of Commemoration Noted (2004). The Neshoba Democrat. Electronic document.

http://www.neshobademocrat.com/main.asp?SectionID=20\&SubSect ionID=330\&ArticleID=8259\& TM=81703.03

Elliot, D. (2004). Truth reconciliation in Neshoba County: Mississippi region grapples with legacy of civil right murders, National Public Radio, June 14, Electronic document.

http://www.npr.org/templates/story/story.php?storyId=1962220

Excerpts from James Young Speech (2004). The Neshoba Democrat. Electronic document.

http://www.neshobademocrat.com/main.asp?SectionID=20\&SubSect ion

Faulkner, W., \& Ford, R. (1959). Requiem for a nun (A play from the novel by William Faulkner adapted to the stage by Ruth Ford). New York: Random House.

Gmelch. S. (2004). Why tourisms matters. In S. Gmelch (Ed.), Tourists and tourism: A reader. Long Grove, IL: Waveland Press.

Gordillo, G. (2006). Landscapes of devils: Tensions of place and memory in the Argentine Chaco. Durham and London: Duke University Press.

Greenwood, D. (2004). Culture by the Pound: An Anthropological Perspective on Tourism as Cultural Commoditization. In S. Gmelch (Ed.), Tourists and tourism: A reader. Long Grove, IL: Waveland Press.

Grupper, I. (2004). Problems with the 40th Neshoba memorial. Labor Paeans. Electronic document. http://www.crmvet.org/comm/csg40iga.htm

Hollowell, A. (2006). Institute spearheads passage of civil rights curriculum bill. The Well Spring, 3, 1.

Horowitz, T. (1998). Confederates in the attic: Dispatches from the unfinished civil war. New York: Random House.

Jackson Proposed as Site For Mississippi Civil Rights Museum (2006). Electronic document. Associated Press. http://diverseeducation.com/article/6792/

Loewe, R., \& Hoffman, H. (2005). A trial 40 years in the making. Cleveland Jewish News.

Maass, P. (1998). The secrets of Mississippi: Post-authoritarian shock in the south. The New Republic.

Mars, F. (1977). Witness in Philadelphia. Baton Rouge, LA: Louisiana State University Press.

Mauss, M. (2000). The gift: The form and reason for exchange in archaic societies. New York: W.W. Norton.

Menkart, D., Murray, A., \& View, J. (2004). Putting the movement back into civil rights teaching: A resource guide for $\mathrm{k}-12$ classes. Teaching for Change and the Poverty and Race Research Council.

Neshoba acknowledges '64 murders (2004). The Neshoba Democrat, 24 June 2004. Electronic document, last accessed on 26 November 2013.

http://www.neshobademocrat.com/main.asp?SectionID=20\&SubSect ionID=330\&ArticleID=8263\&TM=80556.45

Prince, J. (2004). Editorial: Why stir up the past? The Neshoba Democrat. Electronic Document.

http://www.neshobademocrat.com/main.asp?SectionID=20\&SubSect ionID $=334 \&$ ArticleID $=8251 \& \mathrm{TM}=82900.65$

Prince, J. (2004). Editorial: The courage to seek justice. The Neshoba Democrat. Electronic Document.

http://www.neshobademocrat.com/main.asp?SectionID=20\&SubSect ionID $=338$ \&ArticleID $=8258 \& \mathrm{TM}=77697.74$

Rawls, P. (2004). Civil war tourism gives way to civil rights tourism, 


\section{R. LOEWE}

The Anniston Star on the web, 20 November 2004. Electronic document, last accessed on 20 July 2006.

http://www.dailyhome.com.lifestyle/2004/as-ttravel-1120-0-4k19q38 17.htm

Spencer, T. (2006). From civil war to civil rights: Tourism officials repackaging state as interest shifts. The Birmingham News on the web, Electronic document.

http://www.Bhamnews.com/archives/Article ID:Merlin 3043255

Sellers, C., \& Terrell, R. (1990). The river of no return: The autobiography of a black militant and the life and death of SNCC. Jackson, MS: University Press of Mississippi.

Shirley Nichols finds a seat in the back row (2004). The Neshoba Democrat. Electronic document.

http://www.neshobademocrat.com/main.asp?SectionID=20\&SubSect ionID $=330 \&$ ArticleID $=8269 \& \mathrm{TM}=80556.45$
Stern, S. (2006). Battling for hearts and minds: Memory struggles in Pinochet's Chile, 1973-1998. Durham: Duke University Press. http://dx.doi.org/10.1215/9780822388548

Task force to plan commemoration (2004). The Neshoba Democrat, 24 June 2004. Electronic document.

http://www.neshobademocrat.com/main.asp?SectionID=20\&SubSect ionID=332\&ArticleID $=8249 \& \mathrm{TM}=81134.71$

Younge, G. (2005). Racism Rebooted. The Nation. Electronic document.

http://www.thenation.com/article/racism-rebooted

Zubrzycki, G. (2006). The crosses of Auschwitz: Nationalism and religion in Post-Communist Poland. Chicago, IL: University of Chicago Press. http://dx.doi.org/10.7208/chicago/9780226993058.001.0001 